\title{
A TaqMan-based multiplex real-time PCR assay for the rapid detection of tigecycline resistance genes from bacteria, faeces and environmental samples
}

\author{
Yiming Li ${ }^{1}$, Zhangqi Shen ${ }^{1}$, Shuangyang Ding ${ }^{1}$ and Shaolin Wang ${ }^{1,2^{*}}$
}

\begin{abstract}
Background: Tigecycline is a last-resort antibiotic used to treat severe infections caused by extensively drugresistant bacteria. Recently, novel tigecycline resistance genes tet(X3) and tet(X4) have been reported, which pose a great challenge to human health and food security. The current study aimed to establish a TaqMan-based real-time PCR assay for the rapid detection of the tigecycline-resistant genes tet( $(X 3)$ and tet(X4).

Results: No false-positive result was found, and the results of the TaqMan-based real-time PCR assay showed 100\% concordance with the results of the sequencing analyses. This proposed method can detect the two genes at the level of $1 \times 10^{2}$ copies $/ \mu \mathrm{L}$, and the whole process is completed within an hour, allowing rapid screening of tet $(\mathrm{X} 3)$ and tet(X4) genes in cultured bacteria, faeces, and soil samples.
\end{abstract}

Conclusion: Taken together, the TaqMan-based real-time PCR method established in this study is rapid, sensitive, specific, and is capable of detecting the two genes not only in bacteria, but also in environmental samples.

Keywords: Tigecycline resistance, TaqMan, Real-time PCR

\section{Background}

With the prevalence of antimicrobial resistance (AMR), only a few antibiotics are available to treat severe infections caused by extensively drug-resistant (XDR) bacteria, which poses a great challenge to human health and food security. Tigecycline and colistin are last-resort drugs to treat infections caused by carbapenem-resistance Enterobacteriaceae [1]. The World Health Organization (WHO) classified the two antibiotics as critically important antimicrobials, and their usage should be severely restricted (http://www.who. int/foodsafety/publications/antimicrobials-fifth/en/) [2]. Since the recent reports of colistin resistance genes $(\mathrm{mcr})$,

\footnotetext{
* Correspondence: shaolinwang@outlook.com

${ }^{1}$ Beijing Advanced Innovation Center for Food Nutrition and Human Health, College of Veterinary Medicine, China Agricultural University, Beijing, China ${ }^{2}$ Beijing Key Laboratory of Detection Technology for Animal Derived Food Safety and Beijing Laboratory for Food Quality and Safety, Beijing, China
}

the clinical application of colistin has become more limited $[2,3]$, turning tigecycline into the ultimate treatment option.

In May 2019, two tigecycline resistance genes, tet(X3) and tet $(\mathrm{X} 4)$, were discovered, which can inactivate the entire family of tetracycline antibiotics, including tigecycline and the newly US FDA-approved drugs eravacycline and omadacycline [4]. Tet(X3) and tet(X4) are the first plasmid-borne tet $(\mathrm{X})$ genes, encoding proteins with 386 amino acids and 385 amino acids, respectively, and showing 85.1 and $94.3 \%$ identity, respectively, with the original tet $(\mathrm{X})$ from Bacterioides fragilis $[4,5]$.

To date, both genes have been identified in humans, animals, meat, and environmental samples [4, 6-8]. In three representative provinces of China, tet $(\mathrm{X} 3)$ and tet $(\mathrm{X} 4)$ genes have been identified in animals and meat for consumption 
at a high proportion of 43.3\% [4], indicating the wide transmission of tigecycline resistance. Recent studies showed that the presence of tet $(\mathrm{X} 3)$ and tet $(\mathrm{X} 4)$ genes can significantly increase the resistance to tigecycline, and the construction of a tet(X4)-containing bacterial strain, namely, Escherichia coli JM109 + pBAD24-tet(X4), increases the MIC value of tigecycline by 64 -fold compared with the original host strain [8].

Therefore, it is necessary to establish an efficient method for simultaneous screening the tigecycline-resistant genes tet $(\mathrm{X} 3)$ and tet $(\mathrm{X} 4)$ in different samples. Nowadays, realtime PCR assays are widely used in laboratories domestically and overseas. Compared to conventional PCR, real-time PCR has superior sensitivity, reproducibility, precision, and high throughput capability [9]. In this study, we designed a rapid, sensitive TaqMan-based multiplex real-time PCR assay for the specific detection of the tigecycline resistance genes tet(X3) and tet $(\mathrm{X} 4)$, and further evaluated using cultured bacteria, faeces and soil samples.

\section{Results}

\section{Primers and probes}

The results of the NCBI Primer BLAST module indicated that no genes other than $\operatorname{tet}(\mathrm{X} 3)$ and tet $(\mathrm{X} 4)$ genes matched the primer sequences designed in this study. Similarly, the results of conventional and real-time PCR also indicated the high specificity of primers and probes (Fig. 1).

\section{Real-time PCR and standard curve analysis}

Standard curves were obtained using 10-fold serial dilutions of plasmids $\mathrm{pTET}(\mathrm{X} 3)$ and $\mathrm{pTET}(\mathrm{X} 4)$, containing the tet $(\mathrm{X} 3)$ and $\operatorname{tet}(\mathrm{X} 4)$ genes to determine the detection limit of the proposed method. The detection range of copies was $1.49 \times 10^{2}-1.49 \times 10^{10}$ copies $/ \mu \mathrm{L}$ for tet $(\mathrm{X} 3)$ and $1.23 \times 10^{2}-1.23 \times 10^{10}$ copies $/ \mu \mathrm{L}$ for tet $(\mathrm{X} 4)$, and cycle threshold (CT) ranges were 37.435-9.663 for tet(X3) and 36.894-9.273 for tet (X4).

Linear standard curves for real-time PCR are shown in Fig. 2. The amplification efficiencies were calculated using the formula $E=10^{(-1 / \text { slope })}-1$ [10]. $\mathrm{R}^{2}$ values were 0.995 and 0.999 , respectively, and efficiency was 90.58 and $97.12 \%$ for the tet $(\mathrm{X} 3)$ and $\operatorname{tet}(\mathrm{X} 4)$ genes, respectively. The sensitivity of analysis was linear within the dynamic range of 9 dilutions. These results reveal that these two real-time PCR tests are accurate for quantitative detection of tet $(\mathrm{X} 3)$ and tet(X4) genes.

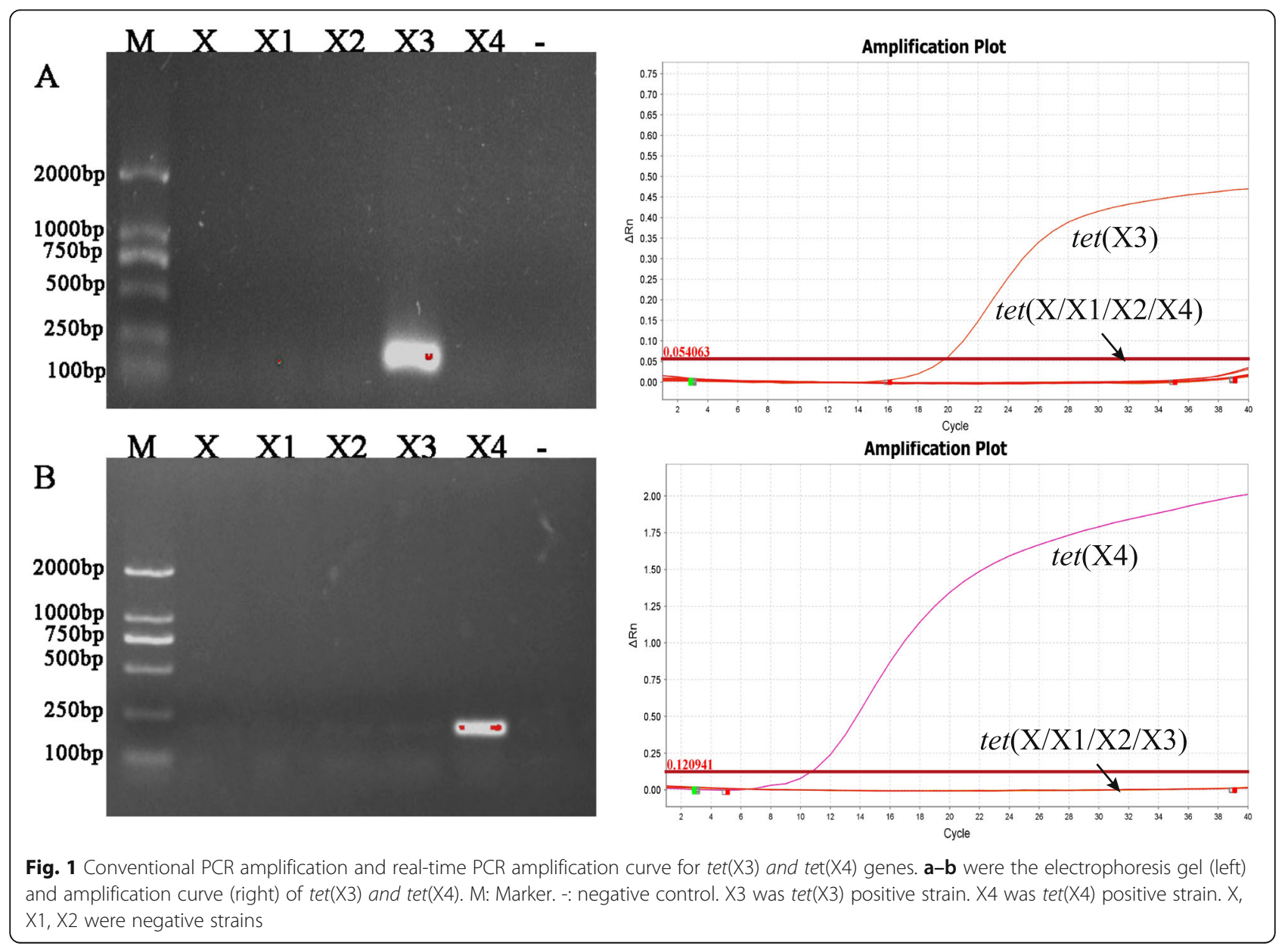



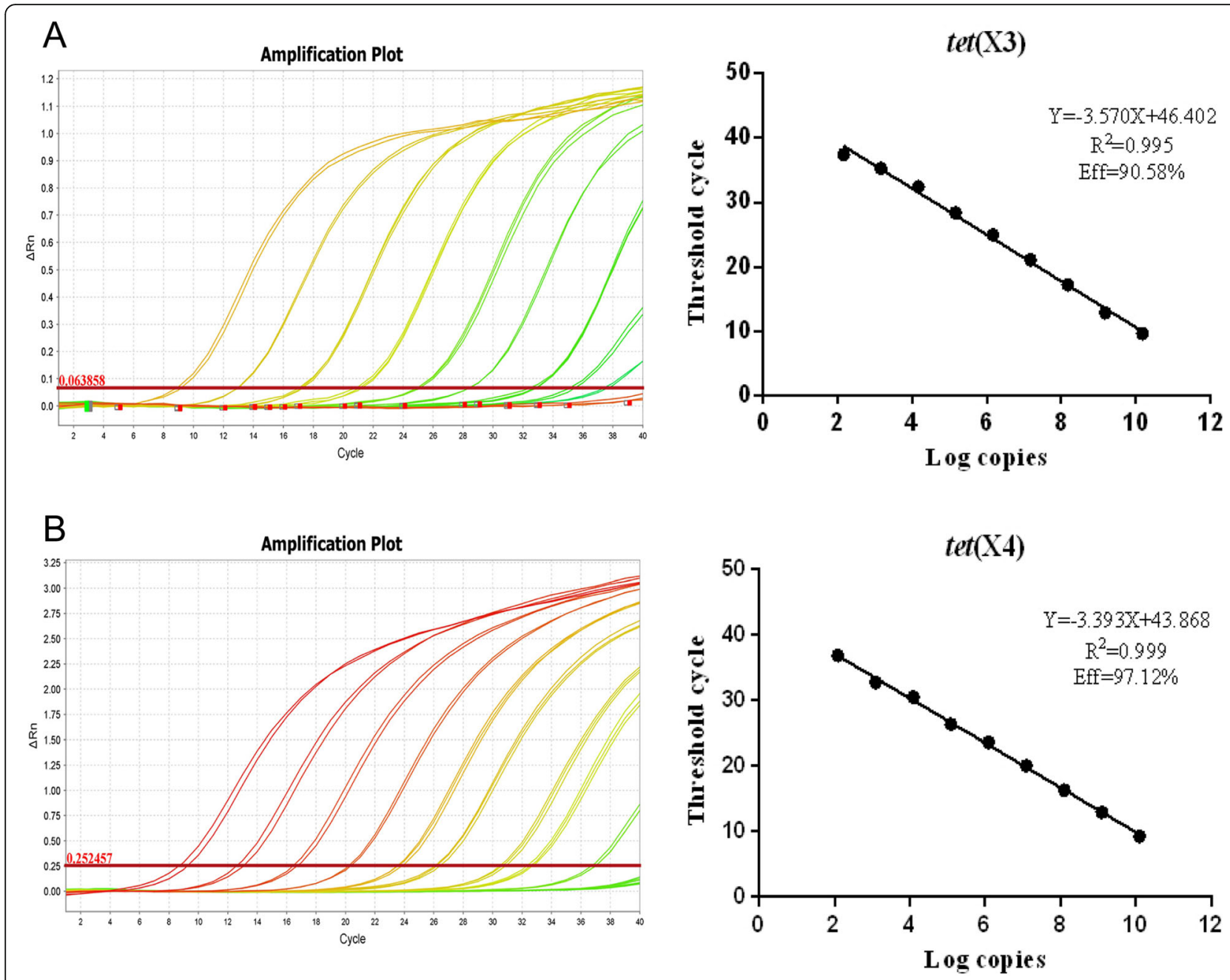

Fig. 2 Real-time PCR amplification curves and standard curves. a-b Show real-time PCR amplification curves and standard curves tet(X3) and tet(X4)

\section{Specificity and sensitivity evaluation}

To confirm the specificity of the assay, two E. coli $\mathrm{DH} 5 \alpha$ strains carrying tet $(\mathrm{X} 3)$ or tet $(\mathrm{X} 4)$ were used as the positive control, while E. coli ATCC25922 and three E. coli $\mathrm{DH} 5 \alpha$ strains containing tet $(\mathrm{X})$, tet $(\mathrm{X} 1)$ or tet $(\mathrm{X} 2)$, respectively, were used as the negative control. Each sample was tested three times independently $(n=3)$. The results of TaqMan-based real-time PCR were 100\% concordance with the results of conventional PCR (Table $1 \&$ Fig. 1), which proved that the two primer sets and probes were highly specific for their target gene.

To further validate the method, genetic DNA extracted from bacteria, faeces and soil samples (three independent technical replicates) was selected to conduct the real-time PCR assay for screening. In this study, some $E$. coli and A. baumannii isolates of animal origin were selected for verification, including 4 tet(X3) positive strains and 8 tet $(\mathrm{X} 4)$ positive strains (Table 1 ). The $\mathrm{CT}$ ranges were 19.05-21.06, 13.42-21.05 for tet $(\mathrm{X} 3)$, tet $(\mathrm{X} 4)$ genes
(Table 1). The results of real-time PCR and previous sequencing analyses were completely consistent, showing high specificity of the method. Moreover, a total of 24 faeces and soil samples from chickens, pigs, and cattle were collected for further evaluation. We were able to detect the two genes in metagenomes extracted from 19 faeces and soil samples, and the relative abundance was normalized using $16 \mathrm{~S}$ rRNA (gene copies $/ 10^{6}$ copies of the $16 \mathrm{~S}$ rRNA gene) $[11,12]$. The real-time PCR assay showed that the normalized copies range from $10^{1}$ to $10^{5}$ for genes tet(X3) and tet(X4) (Fig. 3).

\section{Discussion}

Since the first discovery of the tet $(\mathrm{X} 3)$ and tet $(\mathrm{X} 4)$ genes, these two plasmid-mediated tigecycline resistance genes have been widely reported, suggesting that they are spreading at an alarming rate. It is noteworthy that the tet $(\mathrm{X} 3)$ and tet(X4) genes have been identified not only in humans and animals, but also in the environment $[4,13,14]$. There 
Table 1 Detection of tet(X3) and tet(X4) genes in isolates

\begin{tabular}{|c|c|c|c|c|c|c|c|}
\hline \multirow[t]{2}{*}{ Isolate } & \multirow[t]{2}{*}{ Origin } & \multirow[t]{2}{*}{ Species } & \multirow[t]{2}{*}{ Gene } & \multirow{2}{*}{$\begin{array}{l}\text { Gene } \\
\text { Location }\end{array}$} & \multicolumn{3}{|c|}{ Real-time PCR for tet $(X)$} \\
\hline & & & & & $\operatorname{tet}(\mathrm{X} 3)$ & tet $(X 4)$ & $\mathrm{Ct} \pm \mathrm{SD}$ \\
\hline ATCC25922 & - & E. coli & - & - & - & - & Undetermined \\
\hline DH5a-tet $(X)$ & - & E. coli & $\operatorname{tet}(\mathrm{X})$ & Plasmid & - & - & Undetermined \\
\hline DH5a-tet(X1) & - & E. coli & $\operatorname{tet}(\mathrm{X} 1)$ & Plasmid & - & - & Undetermined \\
\hline $\mathrm{DH} 5 \mathrm{a}-\mathrm{tet}(\mathrm{X} 2)$ & - & E. coli & $\operatorname{tet}(\mathrm{X} 2)$ & Plasmid & - & - & Undetermined \\
\hline DH5a-tet(X3) & - & E. coli & $\operatorname{tet}(\mathrm{X} 3)$ & Plasmid & + & - & $9.66 \pm 0.00$ \\
\hline DH5a-tet(X4) & - & E. coli & $\operatorname{tet}(\mathrm{X} 4)$ & Plasmid & - & + & $9.27 \pm 0.00$ \\
\hline CB13 & Chicken & E. coli & $\operatorname{tet}(\mathrm{X} 3)$ & Plasmid & + & - & $19.05 \pm 0.05$ \\
\hline CB14 & Chicken & E. coli & $\operatorname{tet}(\mathrm{X} 3)$ & Plasmid & + & - & $21.06 \pm 0.08$ \\
\hline CB15 & Chicken & E. coli & $\operatorname{tet}(\mathrm{X} 3)$ & Plasmid & + & - & $19.24 \pm 0.10$ \\
\hline CB42 & Chicken & E. coli & $\operatorname{tet}(\mathrm{X} 3)$ & Plasmid & + & - & $19.24 \pm 0.16$ \\
\hline DZ47 & Chicken & E. coli & $\operatorname{tet}(\mathrm{X} 4)$ & Plasmid & - & + & $21.90 \pm 0.12$ \\
\hline AZ28 & Chicken & E. coli & $\operatorname{tet}(\mathrm{X} 4)$ & Plasmid & - & + & $14.79 \pm 0.01$ \\
\hline DZ4R & Chicken & A. baumannii & $\operatorname{tet}(\mathrm{X} 4)$ & Plasmid & - & + & $13.42 \pm 0.07$ \\
\hline NM4 & Chicken & A. baumannii & $\operatorname{tet}(\mathrm{X} 4)$ & Plasmid & - & + & $14.23 \pm 0.13$ \\
\hline DZ27 & Chicken & E. coli & $\operatorname{tet}(\mathrm{X} 4)$ & Plasmid & - & + & $17.76 \pm 0.13$ \\
\hline DZ24 & Chicken & E. coli & $\operatorname{tet}(\mathrm{X} 4)$ & Plasmid & - & + & $14.35 \pm 0.10$ \\
\hline DZ65 & Chicken & A. baumannii & $\operatorname{tet}(\mathrm{X} 4)$ & Plasmid & - & + & $21.05 \pm 0.05$ \\
\hline DZ24 & Chicken & E. coli & $\operatorname{tet}(X 4)$ & Plasmid & - & + & $18.33 \pm 0.09$ \\
\hline
\end{tabular}

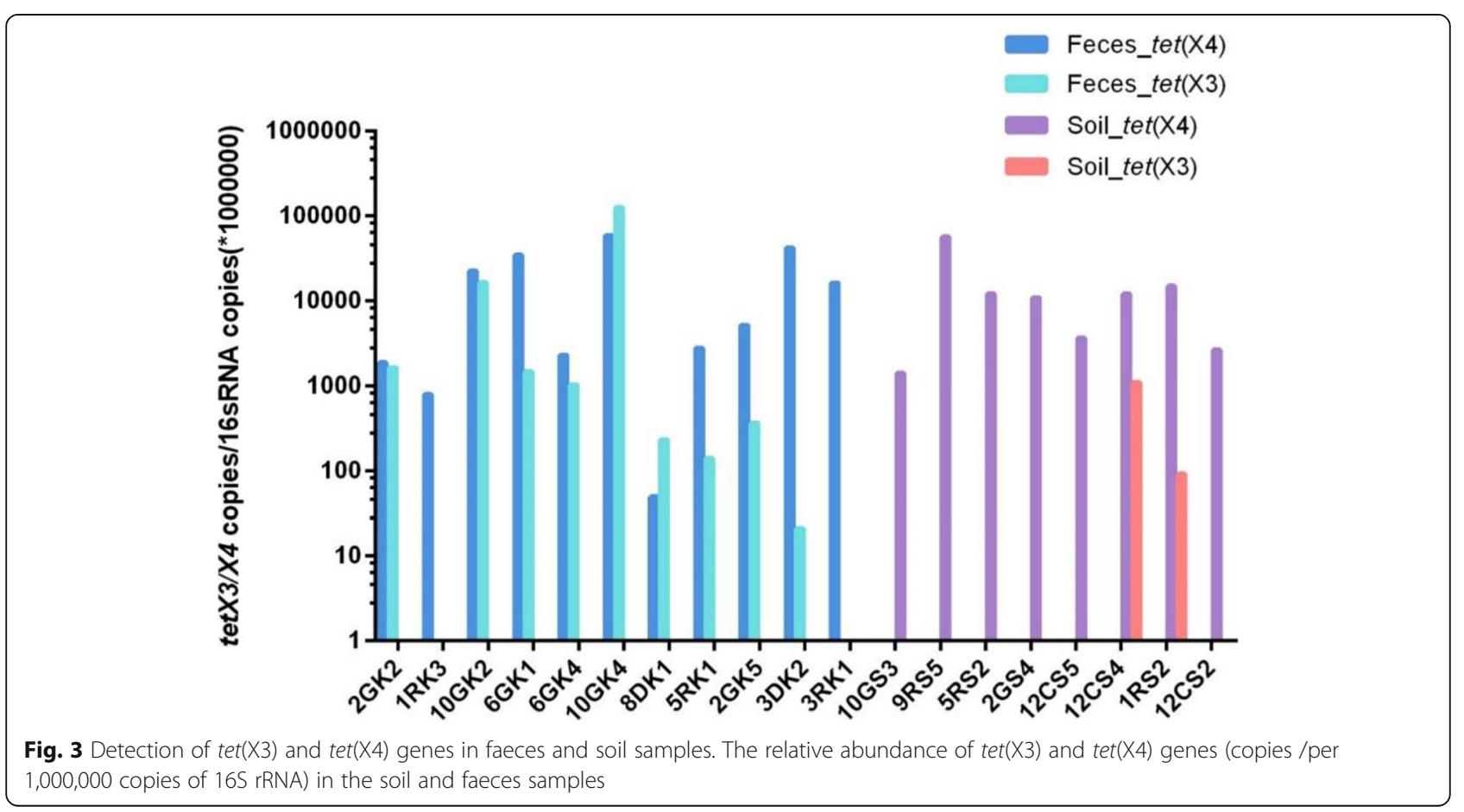


is a pressing need to establish a fast screening assay for tigecycline resistance genes. So far, there are three reports of fast screening of tet $(\mathrm{X} 3)$ and tet $(\mathrm{X} 4)$, multiplex $\mathrm{PCR}$ methods, tetracycline inactivation method, and SYBR Green based real-time PCR, all three methods have approved the effectiveness of methods [15-17]. Compared to traditional detection methods, like conventional PCR and phenotypic method, real-time PCR assays are more sensitive, specific, time-efficient, and labour-saving [18]. Besides, real-time PCR methods can detect genes in different type of samples other than bacteria. Lately, Fu et al. reported a SYBR Green-based real-time PCR assay for rapid detection of $\operatorname{tet}(\mathrm{X})$ variants, with a detection limit range from $10^{2}$ to $10^{5}, 1-10^{3}$ per $10^{6}$ copies of $16 \mathrm{~S}$ rRNA for tet $(\mathrm{X} 3)$ and tet $(\mathrm{X} 4)$, respectively. To date, the method based on realtime PCR using TaqMan probe has not been previously proposed.

In this study, we developed a TaqMan-based multiplex real-time PCR assay for the detection of the tet $(\mathrm{X} 3)$ and tet $(\mathrm{X} 4)$ genes. Both tet $(\mathrm{X} 3)$ and tet $(\mathrm{X} 4)$ genes have been successfully identified not only in bacteria isolates, but also directly from faeces and soil samples, with a minimum of 1 copy per $10^{5}$ copies of 16S rRNA and a maximum of $10^{4}$ copies per $10^{5}$ copies of $16 \mathrm{~S}$ rRNA. Besides, we used constructed E. coli $\mathrm{DH} 5 \alpha$-tet $(\mathrm{X})$ strains as positive control and bacteria isolates of animal origin to evaluate the specificity of the method. The E. coli ATCC25922 was used as negative control. In our method, only specific amplicons can be bonded by TaqMan probes, which is different from the SYBR-Green dye. The SYBR-Green can bind any double strand DNA fragments in the PCR reaction without any specificity, so melting curve analysis will be necessary to identify the single peak for the PCR reaction. According to the Fig. 1, our method has high specificity, whereas other tet $(\mathrm{X})$ genes couldn't be amplified. A limitation of the proposed method is that these genes cannot be detected simultaneously in a single reaction. However, there are no reports of the co-existence of these two genes. Because tet $(\mathrm{X} 3)$ and tet $(\mathrm{X} 4)$ genes are usually accompanied with MDR [9], different combinations of such detection methods are flexible and convenient.

Although tigecycline usage has never been approved in animal husbandry, tetracyclines have been widely used in China and many other countries. The total consumption of tetracyclines reached 13,666 tons in 2018 in China, which may provide ongoing selective pressure for the production of tigecycline resistance genes. Many studies have shown that tet(X4) can be captured by a range of mobile elements circulating among bacterial strains [4, 6-8], importantly, with the international trade of food-producing animals and their derivatives, a novel antibacterial mechanism may appear. It is of great importance to monitor and eradicate these genes, especially in countries with high tetracycline consumption.

\section{Conclusion}

Overall, we developed a TaqMan-based multiplex realtime PCR method in this study for the rapid detection of tigecycline resistance genes, tet $(\mathrm{X} 3)$ and tet $(\mathrm{X} 4)$. This assay can be widely applied to all laboratories equipped with a GPCR machine, and the whole process could be completed within an hour. It is highly sensitive and specific, and can detect and quantify tet(X3) and tet(X4) genes accurately in cultured bacteria isolates, faeces and environmental samples.

\section{Methods}

Bacteria strains and environmental samples

All the E. coli and A. baumannii strains from animal origin used in this study (Table 1) were collected from three poultry farm in Shandong Province, and were identified by conventional PCR and MALDI-TOF before. Five tet $(\mathrm{X})$ variant genes were cloned into the PMD-19 T vector (Takara Bio, Kusatsu, Japan), and then transferred into the DH5 $\alpha$ cell, including DH5 $\alpha$-tet $(\mathrm{X})$, DH $5 \alpha$ tet(X1), DH5 $\alpha-$ tet $(\mathrm{X} 2), \mathrm{DH} 5 \alpha-t e t(\mathrm{X} 3)$ and $\mathrm{DH} 5 \alpha-\operatorname{tet}(\mathrm{X} 4)$ (Table 1). A total of 24 faeces and soil samples collected from chickens, pigs, and cattle farms from Sichuan Province were then used for further evaluation (Fig. 1).

\section{DNA extraction}

Bacteria were incubated at $37^{\circ} \mathrm{C}$ in Brain Heart Infusion broth with agitation at $200 \mathrm{rpm}$ to achieve enough colonies for DNA extraction. Hipure Bacterial DNA Kit (Magen, Guangdong, China) were used to extract bacterial genome according to the manufacturer's instruction. The DNeasy PowerSoil (Qiagen, Hilden, Germany) was used to extract metagenomic DNA from faeces and soil.

\section{Primer and probe design}

The nucleotide sequences of tet(X3) and tet(X4) were obtained from GenBank. The specific real-time PCR primers

Table 2 Primers for real-time PCR detection of tet $(X 3)$ and tet $(X 4)$ genes

\begin{tabular}{|c|c|c|c|c|c|}
\hline Primer & Sequence $\left(5^{\prime}-3^{\prime}\right)$ & Gene & Product length & Accession No. & Reference \\
\hline $\operatorname{tet}(\mathrm{X} 3)-\mathrm{qF}$ & CAGGACAGAAACAGCGTTGC & $\operatorname{tet}(\mathrm{X} 3)$ & $179 \mathrm{bp}$ & MK134375.1 & This study \\
\hline $\operatorname{tet}(\mathrm{X} 3)-\mathrm{qR}$ & GCAGCATCGCCAATCATTGT & & & & \\
\hline $\operatorname{tet}(\mathrm{X} 4)-\mathrm{qF}$ & TTGGGACGAACGCTACAAAG & $\operatorname{tet}(\mathrm{X} 4)$ & $181 \mathrm{bp}$ & MK134376.1 & This study \\
\hline tet $(X 4)-q R$ & CATCAACCCGCTGTTTACGC & & & & \\
\hline
\end{tabular}


Table 3 Probes for detection of tet(X3) and tet(X4) genes

\begin{tabular}{lllll}
\hline Probe & Sequence $\left(5^{\prime}-3^{\prime}\right)$ & Gene & Accession No. & Reference \\
\hline $\operatorname{tet}(\mathbf{X} 3)-P$ & AAGATTTCCAAATGGAGTGAAG & $\operatorname{tet}(\mathrm{X} 3)$ & MK134375.1 & This study \\
$\operatorname{tet}(\mathbf{X} 4)-P$ & TCGTGTGACATCATCT & $\operatorname{tet}(\mathbf{X} 4)$ & MK134376.1 & This study
\end{tabular}

and TaqMan probes for these genes (Tables 2 \& 3) were designed using Primer Express software (ABI-Applied Biosystems Incorporated, Foster City, CA), and the NCBI Primer-BLAST module (https://www.ncbi.nlm.nih.gov/ tools/primer-blast/) was used to initially validate their specificity. Then, conventional and real-time PCR were both conducted to evaluate the specificity of primers and probes.

\section{Standard curves and PCR conditions}

The tet $(\mathrm{X} 3)$ and tet $(\mathrm{X} 4)$ genes were cloned into the pMD19-T vector separately, and then transferred into DH5 $\alpha$ cells. Standard curves were established using realtime PCR on a QuantStudio ${ }^{\text {Tx }} 7$ Flex Real-Time PCR System (ABI-Applied Biosystems Incorporated, Foster City, CA) using 10-fold serial dilutions of the recombinant plasmid DNA with original concentration of $47 \mathrm{ng} / \mu \mathrm{L}$ and $39.4 \mathrm{ng} / \mu \mathrm{L}$ for $\operatorname{tet}(\mathrm{X} 3)$ and tet $(\mathrm{X} 4)$, respectively. Multiplex PCR reactions were performed in a total reaction volume of $20 \mu \mathrm{L}$, including $0.4 \mu \mathrm{L}$ of each primer, $0.4 \mu \mathrm{L}$ of probe, $0.4 \mu \mathrm{L}$ of Passive Reference Dye $(50 \times)$ (TransGen Biotech, Beijing, China), $10 \mu \mathrm{L}$ of $2 \times$ TansStart $^{\circ}$ Probe qPCR SuperMix (TransGen Biotech, Beijing, China), $1.0 \mu \mathrm{L}$ of DNA template, and $7.4 \mu \mathrm{L}$ of $d_{d d} \mathrm{H}_{2} \mathrm{O}$. Each pair of primers and probes were optimized to a final concentration of 0.2 pM. Real-time PCR reaction conditions were as follows: a cycle of $95^{\circ} \mathrm{C}$ for $30 \mathrm{~s}$, followed by 40 cycles of $95^{\circ} \mathrm{C}$ for 5 $\mathrm{s}$ and $55^{\circ} \mathrm{C}$ for $30 \mathrm{~s}$.

\section{Specificity and sensitivity tests}

To evaluate the specificity of the proposed method, $\mathrm{DH} 5 \alpha$ strains containing tet $(\mathrm{X}), \operatorname{tet}(\mathrm{X} 1), \operatorname{tet}(\mathrm{X} 2), \operatorname{tet}(\mathrm{X} 3)$ and tet $(\mathrm{X} 4)$, respectively, were used to conduct the realtime PCR assay (Table 1). Genomic DNA extracted from bacteria, faeces and soil samples from different origin was then used to further validate the specificity and sensitivity of the method.

\footnotetext{
Abbreviations

PCR: Polymerase chain reaction; AMR: Antimicrobial resistance; XDR: Extensively drug resistant; WHO: World Health Organization; FDA: Food and Drug Administration; MIC: Minimal inhibitory concentration; NCBI: National Center for Biotechnology Information; BLAST: Basic Local Alignment Search Tool; CT: Cycle threshold; 165 rRNA: 165 ribosomal Ribonucleic Acid; MDR: Multi-drug resistant; qPCR: Quantitative polymerase chain reaction; MALDI-TOF: Matrix-assisted laser desorption ionization-Time of Flight
}

Authors' contributions

SW, ZS, and SD designed the study; YL performed the experiments; $Y L$ analyzed the data; SW and YL wrote the manuscript. And all authors have read and approved the manuscript.

\section{Funding}

This work was supported in part by the National Key Research and Development Program of China under Grant [2016YFD0501301, 2016 YFD0501304 \& 2016YFD0501305]. None of the funders were involved in designing and conducting of the study, analysis of data, or writing of the manuscript.

\section{Availability of data and materials}

The datasets supporting the conclusions of this article are included within the article. The data and materials used and/or analyzed during the current study are available upon reasonable request to the corresponding author.

\section{Ethics approval and consent to participate}

Not applicable.

\section{Consent for publication \\ Not applicable.}

\section{Competing interests}

No potential conflict of interest was reported by the authors.

Received: 16 March 2020 Accepted: 6 May 2020

Published online: 22 June 2020

\section{References}

1. Rodríguez-Baño J, Gutiérrez-Gutiérrez B, Machuca I, AJCmr P. Treatment of infections caused by extended-spectrum-beta-lactamase-, AmpC-, and carbapenemase-producing Enterobacteriaceae. Clin Microbiol Rev. 2018; 31(2):e00079-17.

2. Liu Y-Y, Wang Y, Walsh TR, Yi L-X, Zhang R, Spencer J, et al. Emergence of plasmid-mediated colistin resistance mechanism MCR-1 in animals and human beings in China: a microbiological and molecular biological study. Lancet Infect Dis, 2016:16(2):161-8.

3. Partridge SR, Di Pilato V, Doi Y, Feldgarden M, Haft DH, Klimke W, et al. Proposal for assignment of allele numbers for mobile colistin resistance (mcr) genes. J Antimicrob Chemother. 2018;73(10):2625-30.

4. He T, Wang R, Liu D, Walsh TR, Zhang R, Lv Y, et al. Emergence of plasmidmediated high-level tigecycline resistance genes in animals and humans. Nat Microbiol. 2019:4(9):1450-6.

5. Guiney DG Jr, Hasegawa P, Davis CE. Expression in Escherichia coli of cryptic tetracycline resistance genes from Bacteroides R plasmids. Plasmid. 1984; 11(3):248-52.

6. Bai L, Du P, Du Y, Sun H, Zhang P, Wan Y, et al. Detection of plasmidmediated tigecycline-resistant gene tet $(X 4)$ in Escherichia coli from pork, Sichuan and Shandong provinces, China, February 2019. Euro Surveill. 2019; 24(25):1900340.

7. Sun C, Cui M, Zhang S, Wang H, Song L, Zhang C, Zhao Q, Liu D, Wang Y, JJEm S, et al. Plasmid-mediated tigecycline-resistant gene tet $(X 4)$ in Escherichia coli from food-producing animals, China, 2008-2018. Emerg Microbes Infect. 2019;8(1):1524-7.

8. Sun J, Chen C, Cui C-Y, Zhang Y, Liu X, Cui Z-H, et al. Plasmid-encoded tet $(X)$ genes that confer high-level tigecycline resistance in Escherichia coli. Nat Microbiol. 2019:4(9):1457-64.

9. Higuchi R, Fockler C, Dollinger G, Watson R. Kinetic PCR analysis: real-time monitoring of DNA amplification reactions. Nat Biotechnol. 1993;11(9):102630

10. Subirats J, Royo E, Balcázar JL, Borrego CM. Real-time PCR assays for the detection and quantification of carbapenemase genes (Bla KPC, Bla NDM, 
and Bla OXA-48) in environmental samples. Environ Sci Pollut Res Int. 2017; 24(7):6710-4.

11. Zhao $Q$, Yang $W$, Wang $S$, Zheng W, Xiang-dang $D$, Jiang $H$, et al. Prevalence and Abundance of Florfenicol and Linezolid Resistance Genes in Soils Adjacent to Swine Feedlots. Sci Rep. 2016;6:32192.

12. Weiwei $B$, Jian W, Xun P, Zhimin Q. Dissemination of antibiotic resistance genes and their potential removal by on-farm treatment processes in nine swine feedlots in Shandong Province, China. Chemosphere. 2017;167:262-8.

13. Chen C, Chen L, Zhang Y, Cui C-Y, Wu X-T, He Q, Liao X-P, Liu Y-H, Sun J. Detection of chromosome-mediated tet (X4)-carrying Aeromonas caviae in a sewage sample from a chicken farm. J Antimicrob Chemother. 2019; 74(12):3628-30.

14. Chen C, Cui C-Y, Zhang Y, He Q, Wu X-T, Li G, et al. Emergence of mobile tigecycline resistance mechanism in Escherichia coli strains from migratory birds in China. Emerg Microbes Infect. 2019;8(1):1219-22

15. Ji K, Xu Y, Sun J, Huang M, Xu J, Jiang C, et al. Harnessing efficient multiplex PCR methods to detect the expanding Tet(X) family of Tigecycline resistance genes. Virulence. 2020;11(1):49-56.

16. Cui Z-H, Ni W-N, Tang T, He B, Zhong Z-X, Fang L-X, et al. Rapid Detection of Plasmid-Mediated High-Level Tigecycline Resistance in Escherichia Coli and Acinetobacter Spp. J Antimicrob Chemother. 2020. https://doi.org/10. 1093/jac/dkaa029.

17. Yulin F, Liu D, Song H, Liu Z, Jiang H, Wang Y. Development of a multiplex real-time PCR assay for rapid detection of Tigecycline resistance gene tet $(X)$ variants from bacterial, faeces, and environmental samples. Antimicrob Agents Chemother. 2020;64(4):e02292-19.

18. Law JW-F, Ab Mutalib N-S, Chan K-G, Lee L-HJ. Rapid methods for the detection of foodborne bacterial pathogens: principles, applications, advantages and limitations. Front Microbiol. 2015;5:770.

\section{Publisher's Note}

Springer Nature remains neutral with regard to jurisdictional claims in published maps and institutional affiliations.

Ready to submit your research? Choose BMC and benefit from:

- fast, convenient online submission

- thorough peer review by experienced researchers in your field

- rapid publication on acceptance

- support for research data, including large and complex data types

- gold Open Access which fosters wider collaboration and increased citations

- maximum visibility for your research: over $100 \mathrm{M}$ website views per year

At $\mathrm{BMC}$, research is always in progress.

Learn more biomedcentral.com/submissions 